\title{
Trends in Education for Sustainable Development in Some Former Soviet Countries (Use of ESD Potential for Provincial and Regional Studies)
}

\author{
Efim Vyshkin \\ Samara State University of Architecture and Civil Engineering. \\ Address: ul.Molodogvardeyskaya, 194, Samara, 443001, Russia
}

\begin{abstract}
The major part of the decade for education on sustainable development declared by United Nation in 2005 is over and it is the time to review the outcomes of the efforts of national and international educational and research communities. These results differ greatly. One of the ways to grasp the picture is to look at the map of regional centres of expertise on education for sustainable development organized under the aegis of United Nations University and with its help. The biggest states formed on the ruins of the collapsed Soviet Empire are the most backward ones in this respect. For instance on the huge territory of Russia there are only two such centres, in Samara and Nizhny Novgorod. There are certain political, geographical, economic, social and even linguistic factors deterring the implementation of sustainable development methodology in national education systems. Nevertheless it can be fruitfully used on a regional level. This was proved at a number of international research conferences on provincial life and environment held at Samara State University of Architecture and Civil Engineering. A great potential of this philosophy for regional studies even in such restrictive conditions was revealed.
\end{abstract}

Keywords - sustainable development, CIS countries, regional studies, provincial identity.

Most of the former Soviet Union Republics (with the exception of Baltic countries and Georgia) still share many common features inherited from the collapsed empire. For example, the organizational structure of the higher education systems of such countries as the Russian Federation, Ukraine or Kyrgyzstan are similar to a great extent. Nevertheless nowadays all of them are undergoing substantial changes caused by the rapid introduction of the Bologna principles for $\mathrm{HE}$ coming from the West. That is why there are still two parallel ways of acquiring HE in these countries: a traditional one-level educational system leading to a specialist diploma (57 years depending on the chosen specialty) and an European «newcomer», a two-level training system with bachelors and masters degrees, following the European model. The Bologna process was supported by official documents. Russia joined it officially in 2003 at the Berlin Meeting of European Ministers of Education [1]. In 2005 the Bologna Declaration was signed by the Minister of Education of Ukraine[2]. Kyrgyzstan is going to join it and is already adopting this system as well [3]. At the moment there is an overall transition to this new system which is ousting the former one, but there are also attempts to adjust specialist diplomas as an alternative to master degrees in post-bachelor education. Postgraduate education still includes the two academic degrees inherited from the Soviet system, the Candidate of Science and
Doctor of Science, which are not easily comparable with European doctoral degrees.

The most common university model in all the three countries is still a state centered institution operating on prescriptions of state regulative bodies.

There are two general types of such institutions of higher education: state (public) and private. In all these countries the number of state universities prevails over the number of private universities: in Russia the number of state universities is 653 out of the total number of $1115(59 \%)$, in Ukraine this proportion is 316 to $451(70 \%)$ and in Kyrgyzstan the percentage is even higher, it is $72 \%$ (36 out of 50). If we compare the numbers of university students with the whole population we shall see that there are relatively more students in Ukraine $(5,7 \%)$, than in Russia $(4,9 \%)$ and Kyrgyzstan $(4,3 \%)$ though in absolute figures Russia is taking the lead due to its immense size. But in the public spending on education the Kyrgyz Republic is ahead with circa $18.7 \%$ of the total national budget while in Russia it is $16.7 \%$, and in Ukraine it is only $12.6 \%$ of the budget.

The key institutions responsible for HE policies are corresponding national Ministries of Education and Science and their subordinate or authorized agencies. They set federal or national state educational standards which rather precisely define obligatory requirements for the structure and content of higher professional education. The standards allow some freedom of choice only in some minor or elective 
courses. ESD is not included in the content of the standards, because the notion of Sustainable Development is relatively new for the general public in these countries. Only recently it has started to be used in official speeches and documents and mainly only for "decorative" purposes: e.g. new educational standards are said to be developed for the sake of sustainable development. (cf: Federal State Educational Standard - Strategic Resource of Multinational Society Sustainable Development) [4]. In the same way the term SD was used in an article by Russian PM V. Putin in "Komsomolskaya Pravda" on $12 / 02 / 2012$. This notion is neither included in the content of the federal or national state educational standards nor it is expressed in the national educational programs or state education development projects, except for those involving EU institutions.

The idea of SD was first mentioned in Russia at the legislative level in 1994 by Presidential Decree №236 "On the Russian Federation National Strategy of Environmental Policy and Providing Sustainable Development" of 04.02.1994 [5]. A similar situation could be observed in Ukraine, where the issue of SD was first raised in the framework of the "Conception of Settlements Development", adopted by the Verkhovna Rada of Ukraine on the $24^{\text {th }}$ of December 1999. In both countries it has not made any immediate impact on HE and generally speaking no real measures necessary for implementing principles of SD have followed. In the Kyrgyz Republic the issues of education for sustainable development were first considered in "Conception for Transfer of Kyrgyz Republic to Sustainable Development until 2010”, which was adopted in 2002 and all initiatives in the sphere of SD since than have been supported by the Government and Ministry of Education. The reason for such a difference between national approaches to SD implementation may be the relative compactness of Kyrgyzstan in comparison with the Russian Federation and Ukraine combined with the fact that SD ideas were introduced later when they were more clearly defined and made more applicable for implementation in HE. The first definition of SD borrowed by all these countries from the West was rather general - SD was defined in 1987 by the World Commission on Environment and Development as a development that satisfies the needs of the present time, but doesn't endanger the ability of future generations to satisfy their needs. Only later was it further elaborated, specified and clarified.

There are still some differences in the national attitudes to this term. For example, in Russia the idea of SD is still perceived with a kind of skepticism. The main reason for this is a disbelief in the possibility of its implementation under the conditions of present day Russia; it is often regarded as utopian and excessively ambitious. The other reason is that the Russian translation of this term is not accurate and is understood by Russian speakers primarily as "stable" development without considering the multifaceted complexity of this notion. There is also a political reason: many influential politicians say it should be not applicable in Russia or other non-western civilizations because of its Western origin. We can add to that the widespread fear that the concept of sustainability could have a negative impact on industrial development and the limitations of the latter would lead to undesirable consequences.

In Ukraine there are no explicit anti-western arguments, but the other reasons are mainly the same. There is less anti-Westernism in Kyrgyzstan as well. This country focuses more strongly on cooperation with Europe.

In all the given countries the notion of SD was historically closely related with that of ecological protection. Even now these issues and terms are often interchanged and SD is limited to environment protection in the minds and practices of the general public. At the same time there is one thing common for all the countries - concerns for all the aspects inherent for SD, namely social, health, educational, ecological, economic and other priorities, regularly formulated in spite of various conceptual and ideological differences. These challenges nowadays are faced separately, each within its own domain or sphere. Unfortunately there is no awareness that the idea of SD could provide a unified remedy for the successful joint and balanced treatment of those challenges. To be efficient SD needs to be mainstreamed, in education it could find its expression in transdisciplinarity.

Regrettably in Russia and Ukraine there is no national strategy for introducing $\mathrm{SD}$ into $\mathrm{HE}$, developed and approved at the legislative level. Since its coming in the 90-s to Russia these ideas have been closely associated mainly with the sphere of ecology, starting with Presidential Decree № 236 of 4.02.1994 and then followed in other official documents such as the National Action Plan of the Environment and Natural Resources Ministry of the Russian Federation "On Environmental Education in Educational Institutions of the Russian Federation" (1994); Presidential Decree № 440 of 1.04.1996 "On Concept of Russian Federation's Transition to Sustainable Development"; and the "Concept of Secondary Ecological Education"[6].

None of these documents pay attention to HESD, neither do they consider other, non-environmental aspects of sustainable development. Maybe that is why a comprehensive strategy of ESD has not been developed up to the present in spite of the fact that it was many times declared. Even the mass media are still not greatly involved in the process of promoting ESD.

At the moment some awareness and activities related to HESD can be seen at regional and local levels. Several specialized institutions have been created (i.e. the Institute for Globalization and SD at the International Independent Ecological University in Moscow), a number of UNESCO Chairs related to SD 
have been organized at some Russian Universities, ESD ideas are being developed rather sporadically at HEIs such as Moscow State University, the Russian State Humanitarian University, the Mordovian State Pedagogical Institute and many others. Under the aegis of the UN University two Regional Centers of Expertise on Education for Sustainable Development were created in Russia, at Samara State University of Architecture and Civil Engineering (2007), and at Nizhny Novgorod State University of Architecture and Civil Engineering (2009). Another RCE on ESD was organized in Kyrgyzstan.

In Ukraine as well as in Russia there is no real national policy strategy. SD is not on the list of national priorities. It is also mentioned in some national documents, but the main initiatives are coming from NGOs. We can mention here the Regional Social Ecological Organization "Center of Sustainable Development "Roza Vetrov", the World Social-Ecological Union, the World Data Centre on Geoinformatics and Sustainable Development (WDCUkraine), and the Municipal Governance and Sustainable Development Programme. Special courses on SD have been organized in some universities, such as Kievo-Moghilyanskaya Academy, Kiev National University, Odessa Ecological University, and the Management Education University. In these universities special chairs were set up and new educational programs were developed.

More positive tendencies can be noticed in the Kyrgyz Republic. The Government here is constantly expanding the range of issues related to SD. Certain significant commitments were made as a result of different international projects. They are oriented to the integration of SD topics into study programs, such as "Biological and Landscape Diversity", "Citizenship, Democracy and/or Management", "HIV/AIDS, Drug Abuse", "Healthy Life Style", "Cultural Diversity" and "Climate Change". A crosscurricular approach in the sphere of ESD is under active development at the moment in Kyrgyzstan. A broad awareness campaign on ESD issues for schools and institutions of higher education of Kyrgyzstan is underway. Many teachers of higher educational institutions in recent years have been trained in the frameworks of various international projects.

In comparison with the situation in Russia and Ukraine the ESD issues in Kyrgyzstan are reflected in some national strategic documents, such as the State Doctrine of Education of the Kyrgyz Republic (adopted in August 2002 by order of the President of the Kyrgyz Republic), the Concept of Education Development of the Kyrgyz Republic up to 2010 (adopted in 2002), the Concept of Continuous Environmental Education in Kyrgyzstan, adopted by decision of the Ministry of Education and Science Board of the KR on September 17th, 2003.

In relation to the issues of environmental education, it is important to notice that they are partially reflected in the following national political documents, such as the President Education Program "Human Resources of the XXI century" (by Order of the President of the KR on September 11th, 1995, \# OP-218), laws "On Environmental Protection" and "On Environmental Expertise" (1999), Conception for Transfer of Kyrgyz Republic to Sustainable Development until 2010 (August 2nd, 2002) and the KR Law "On Education" of April 30th, 2003, \# 92.

In Kyrgyzstan state and non-state organizations were created for the implementation of Sustainable Development principles. Such state organizations as the State Agency of Environment and Forestry, the State Environmental Fund and the Forestry Development and Coordination Council of Education for Sustainable Development could be mentioned. Non-State Organizations include the Ecological Movement "BIOM", RCE Kyrgyzstan, EHD Aleine" and the non-state public organization "Institute of Equal Rights and Opportunities". Kyrgyz National University, Kyrgyz State University and Kyrgyz Russian Slavonic University also support and develop the ideas of SD.

Thus, Kyrgyzstan can be regarded as the leader among the above-mentioned countries in promoting HESD. Due to its small territory it's easier to integrate the ideas of SD in all spheres of society. Besides, all reforms in the educational sphere are willingly supported by the Government.

Coming back to the issue of using ESD for regional and provincial studies we can refer to the experience of RCE Samara, where a number of international conferences on the topic were held recently.

\section{CONCLUSIONS}

Summing up we should underline that there still exist certain challenges in implementing / disseminating sustainability in higher education:

1. There are no political/state/legal documents which explicitly promote SD in Education. Sustainable Development as a specialized course started to appear in curricula mostly in ecological specialities only a couple of years ago and it is still at the developmental stage.

2. Universities are very strictly controlled by the Ministry of Education: universities should plan the curricula according to the instructions of the Ministry of Education but not to the current challenges in the ecological, economical, and social spheres. Poor financing of research in SD at HEIs limits the progress of its implementation.

3. Low awareness about the idea of SD among the majority of professionals. Mostly only ecologists and sometimes economists are involved.

4. There are relatively few examples of successful practice in these countries to be used as case studies for students. Many SD initiatives have been recently cancelled because of political and financial pressure as well as because of corruption.

5. Implementing / disseminating of sustainability is done mostly via NGOs. It is necessary to develop 
interactions between NGOs and high school institutions. Unfortunately such cooperation is not

\section{REFERENCES}

[1] Live Journal "Yabloko", press-release of 19.09.2003 "Russia joined the Bologna Process" URL:http://www.eng.yabloko.ru/Press/2003/9/030919.h tml

[2] Official website of Council of Europe URL:http://www.coe.int/T/DG4/HigherEducation/ EHEA2010/BolognaPedestrians_en.asp

[3] Data portal of Kyrgyz Republic URL:http://www.kginform.com/ru/news/20110829/0435 1.html very common currently. Especially after the notorious law was adopted in Russia.

[4] Legislative Initiative of Russian Federation Subjects: Recommendations of Parliamentary Hearings on 02/19/2009 //. Official Documents in Education - 2009. - №12. - P.7-11;

[5] Data portal "Konsultant Plus" URL:http://base.consultant.ru/cons/cgi/online.cgi?req=d oc\&base $=$ LAW \&n $=3079$

[6] Data Portal "Laws of Russian Federation" URL:http://lawrussia.ru/texts/legal_790/doc790a100x64 2.htm 